\title{
Rancang Bangun Fault Tolerance pada Sistem Database untuk Aplikasi Point Of Sale
}

\author{
S. Oei dan A. Ashari
}

\begin{abstract}
A fault tolerant system is a system that has the ability to be able to continue its jobs properly although there is a fault in hardware or software of the system. A system that has a fault tolerant capability is usually critical or important system. For example is at Point Of Sale application. Point Of Sale Application has evolved from offline-based toward online-based. With an online-based, the existence of a central database server must be guaranteed free from failure.

To get a central database server that is free from failure is impossible. Something that can be cultivated is to create a system that can tolerate a failure in the central database server. This is done with the help of a second central database server (slave), which is useful as a replication of the central database server (master). To ensure data from these two central database servers are the same, then used the concept of reading and writing "read one/write all". And to manage all the processes needed in implementing a fault tolerant application, we need the help from a coordinator.

The result obtained in this research is a design of fault tolerant architecture that can be applied to various types of information system applications include Point Of Sale application. By using this fault tolerant architecture that has been built, Point Of Sale application can still run the transaction process even if there is a failure in accessing data in one central database server (master/slave).
\end{abstract}

Keywords- fault tolerance, database system, point of sale application

\section{PENDAHULUAN}

$\mathrm{D}$ ewasa ini penggunaan sistem komputer telah meluas ke berbagai aspek kehidupan manusia. Baik untuk sistem pertahanan, sistem penerbangan, sistem kendali lalu-lintas, sistem perbankan, ataupun untuk sistem informasi. Berbagai aplikasi telah dibuat dengan menggunakan sistem komputer guna menunjang aktivitas manusia. Hal ini mengakibatkan adanya ketergantungan manusia akan sistem komputer.

Standy Oei, Mahasiswa Program Pascasarjana Ilmu Komputer, Fakultas Matematika \& Ilmu Pengetahuan Alam, UGM, Yogyakarta

Ahmad Ashari, Staf Pengajar Program Pascasarjana Ilmu Komputer, Fakultas Matematika \& Ilmu Pengetahuan Alam, UGM, Yogyakarta.
Ketika sistem komputer mengalami masalah, maka aktivitas yang dikerjakan manusia itu akan terhambat ataupun terhenti sama sekali. Dimulai dari sinilah muncul suatu pemikiran untuk membuat suatu sistem komputer yang memiliki kemampuan toleransi terhadap masalah kegagalan sistem yang bisa akan muncul (fault tolerant system). Dimana salah satu masalah kegagalan sistem yang bisa muncul yakni pada sistem database. Dan hampir semua aplikasi sistem informasi dibuat menggunakan database sebagai tempat penyimpanan data.

Aplikasi Point Of Sale (POS) merupakan salah satu contoh dari aplikasi sistem informasi, yang digunakan untuk mempermudah proses pencatatan transaksi penjualan barang, dimana aplikasi ini biasa ditempatkan di lokasi pembayaran barang (kasir) seperti yang ada di minimarket ataupun supermarket.

Aplikasi Point Of Sale telah berkembang dari berbasis offline menuju ke berbasis online. Dengan berbasis online, semua aplikasi Point Of Sale yang tersebar di semua kasir penjualan akan sangat bergantung terhadap eksistensi dari server database pusat. Dari sinilah muncul adanya kebutuhan untuk mengaplikasikan kemampuan fault tolerant ke dalam aplikasi Point Of Sale agar bisa mentolerir kegagalan yang mungkin saja akan terjadi pada server database pusat.

Masalah fault tolerant, aplikasi Point Of Sale, beserta query processing telah banyak dikembangkan dalam berbagai penelitian. Beberapa penelitian yang telah membahas masalah berkaitan dengan penelitian ini diantaranya adalah sebagai berikut.

Pada penelitian [1] menunjukkan bukti bahwa pengembangan sebuah aplikasi menggunakan query processing bisa dilakukan dan bahkan membuat lebih mudah bagi programmer dalam membangun aplikasi. Software DBMS yang digunakan adalah MySQL, dimana MySQL ini merupakan software DBMS yang open source dan powerful. Selain itu juga, MySQL membangun sistemnya berdasarkan query processing.

Pada penelitian [2] membahas tentang perancangan dan pembuatan Sistem Informasi 
Akademik yang Fault Tolerance menggunakan metode replikasi data antar database. Dimana dalam mensikronkan data atau recovery data antar database digunakan cara backup dan restore data dari satu database ke database yang lain.

Pada penelitian [3] membahas software fault tolerant yang diaplikasikan pada sistem terdistribusi. Fault tolerant ini diaplikasikan pada fieldbus yang dipergunakan dalam sistem terdistribusi. Saat ini sudah banyak fieldbus yang dipergunakan di industri, di antaranya Control Area Network (CAN), Profibus, I2C, dan lainlain. Dalam pembahasan ini menggunakan CAN dan SPORT (Serial Port) untuk membangun sistem terdistribusi dengan fault tolerant.

Pada penelitian [4] membahas tentang teknik yang digunakan dalam meningkatkan service availability, seperti melalui teknik redundancy, machine virtualization, dan autonomic service placement. Konsep availability didefinisikan sebagai kemungkinan/probabilitas sebuah sistem untuk bisa hidup dan siap untuk digunakan. Availability bisa dirumuskan lewat sebuah persamaan berikut ini: availability $=M T B F /$ $(M T B F+M T T R)$, dimana $\mathrm{MTBF}=$ mean time between failure dan MTTR = mean time to repair.

Pada penelitian [5] membuat suatu rancangan Heterogeneous Replicated Database (HRDB). HRDB merupakan suatu rancangan fault tolerant DBMS yang mengimplementasikan sebuah skema replikasi praktis dalam mengatasi permasalahan kegagalan database (database faults). Seperti pada penelitian yang telah ada sebelumnya, HRDB menggunakan teknik replikasi, tetapi HRDB menggabungkan dua ide kunci dalam mengatasi permasalahan yang telah muncul sekarang ini. Pertama, untuk mencapai failure-independence, HRDB menggunakan heteregeneous replicator. Kedua, untuk mengatasi Byzantine failures, HRDB menggunakan voting. Arsitektur rancangan HRDB yang dibuat adalah seperti pada Gambar 1.

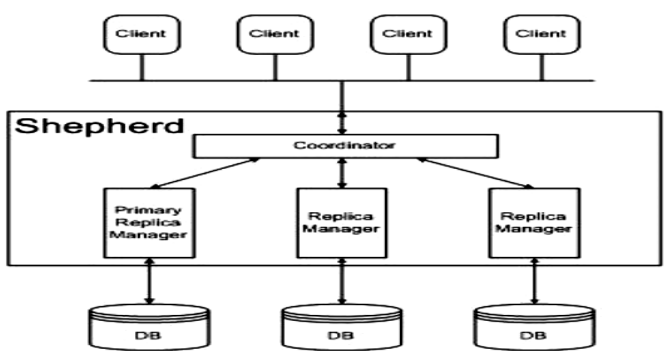

Gambar 1 Arsitektur perancangan HRDB

\section{Metode PENELITIAN}

\subsection{Analisa Sistem}

Sistem yang akan dirancang dan dibangun dalam penelitian ini adalah sistem yang memiliki kemampuan fault tolerant dalam mengatasi permasalahan kegagalan pengaksesan data pada salah satu server database pusat, yang diakibatkan oleh kerusakan komponen. Kerusakan yang dimaksud seperti putusnya koneksi kabel jaringan pada server database pusat, serta kerusakan secara permanen pada komponen penting di server database pusat yang menunjang ketersediaan data (seperti prosesor, hardisk, memori, kartu jaringan (network card), motherboard dan power supply).

Contoh penerapan yang diangkat disini adalah pada aplikasi Point Of Sale. Server database pusat yang akan digunakan berjumlah 2 buah, yakni master dan slave. Dalam mengakses data pada server database pusat, client tidak berinterakasi langsung dengan server database pusat. Melainkan client harus berkomunikasi dengan sebuah coordinator. Dimana dalam coordinator inilah fungsi fault tolerant itu dilakukan.

Coordinator berfungsi sebagai pengeksekusi request (query) dari client dan sekaligus berguna sebagai buffer untuk menyimpan log dari query yang gagal untuk dieksekusi pada server database pusat (master ataupun slave). Coordinator bisa secara pintar memilih menggunakan server database pusat mana yang sedang hidup. Dan setelah server database pusat (master atau slave) yang gagal diakses sebelumnya bisa kembali bekerja normal, maka isi dari buffer (pada coordinator) yang berisi query bisa dikosongkan dengan cara dengan mengeksekusi kembali semua query yang gagal dieksekusi sebelumnya (proses recovery).

Aplikasi Point Of Sale yang akan dibangun menggunakan metode one-copy serializability [6] dalam proses pengaksesan data pada kedua server database pusat baik master ataupun slave. Implementasi dari metode ini bisa diilustrasikan dengan kata read one/write all, yakni aplikasi Point Of Sale akan melakukan pembacaan data dari salah satu server database pusat dan akan melakukan penulisan ke semua server database pusat yang ada. Hal ini berguna untuk menjamin isi dari kedua server database pusat tersebut mempunyai isi data yang sama.

Dengan adanya kemampuan fault tolerant ini, aplikasi Point of Sale bisa terus melakukan 
kerjanya walaupun terdapat salah satu server database pusat yang mati.

Sistem yang akan dibangun ini mempunyai karakteristik sebagai berikut:

1. Aplikasi Point Of Sale yang akan dibangun merupakan aplikasi yang berbasis desktop.

2. Aplikasi Point Of Sale dijalankan pada sistem jaringan LAN (Local Area Network).

3. Aplikasi Point Of Sale (Client), Coordinator, dan Server Database pusat dijalankan pada sistem operasi windows.

4. Coordinator diasumsikan akan selalu hidup atau bisa diakses agar fungsi fault tolerant yang telah dibangun bisa berjalan.

5. Masalah utama yang diperhatikan adalah kemampuan dari aplikasi Point Of Sale dalam mentolerir kegagalan pengaksesan dari salah satu server database pusat, dan melakukan proses recovery data dengan menggunakan log query yang ada.

6. Interkoneksi antara client, coordinator, dan server database pusat masih sepenuhnya mengandalkan kemampuan dari Winsock dan MySQL Connector atau ODBC.

\subsection{Perancangan Arsitektur Sistem Fault Tolerant}

Dalam membangun suatu sistem yang fault tolerant diperlukan adanya suatu analisa terhadap perancangan dari sistem tersebut. Analisa diperlukan untuk bisa menggambarkan suatu arsitektur yang menunjang penerapan fault tolerance di dalam sistem. Suatu arsitektur yang dibangun haruslah bisa menjelaskan bagaimana suatu proses fault tolerant dilakukan di dalam sistem. Gambar 2 merupakan rancangan dari arsitektur fault tolerant yang akan dibangun.

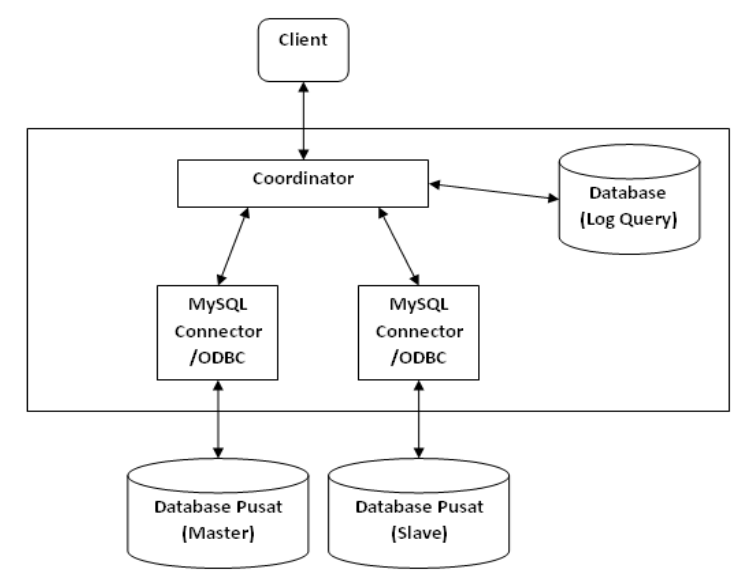

Gambar 2 Rancangan arsitektur fault tolerant

Pada rancangan ini, tidak dibutuhkan adanya modifikasi terhadap software database yang digunakan. Dan tidak diperlukan adanya suatu software khusus yang dijalankan pada server database pusat (master ataupun slave). Hal ini didukung karena software DBMS yang digunakan sudah menawarkan suatu standar antarmuka SQL dan menyediakan protokol komunikasi yakni ODBC.

Client tidak berinteraksi secara langsung dengan setiap server database pusat (master atau slave). Tetapi client berkomunikasi dengan sebuah coordinator, yang bertindak sebagai sebuah front-end ke database dan mengatur atau mengkoordinasikan client yang ada.

Untuk melakukan penulisan (write), client mengirimkan SQL statement ke coordinator. SQL statement yang tiba di coordinator kemudian akan dieksekusi ke kedua server database pusat (master dan slave) lewat protokol komunikasi ODBC. Dimana setiap server database pusat memiliki koneksi ODBC masingmasing. Ketika terdapat suatu server database pusat (master atau slave) yang gagal mengeksekusi SQL statement yang telah diberikan tersebut, maka coordinator akan mencatat SQL statement (query) yang gagal dieksekusi ke dalam database (log query). Ketika sukses mengeksekusi SQL statement yang dikirim oleh client, coordinator akan mengirim kembali respon atau jawaban kepada client. Dalam berkomunikasi antara client dan coordinator digunakan protokol komunikasi Winsock.

Ketika server database pusat yang telah mati sebelumnya bisa kembali beroperasi, maka semua catatan query yang gagal dieksekusi ke dalam server database pusat tersebut bisa dieksekusi kembali. Sekaligus isi dari database ( $\log$ query) bisa kembali dikosongkan ketika query yang gagal dieksekusi tersebut bisa sukses dieksekusi kembali. Dimana semua proses recovery ini dikendalikan atau dilakukan sepenuhnya oleh coordinator.

Untuk melakukan pembacaan (read), client melakukan pemanggilan suatu prosedur yang ada di dalam coordinator. Hal ini dilakukan dengan cara mengirimkan nama prosedur dan informasi tambahan yang dibutuhkan dalam menjalankan prosedur tersebut ke coordinator. Kemudian coordinator akan menjalankan prosedur pembacaan tersebut ke salah satu server database pusat (master atau slave) yang masih hidup. Setelah mendapatkan hasil pembacaan, maka coordinator akan mengirimkannya ke client.

Pada intinya, proses penulisan data dilakukan pada kedua server (write all) dan proses pembacaan data dilakukan pada salah satu server 
(read one). Hal ini dilakukan untuk menjamin kedua server database pusat mempunyai isi data yang sama. Gambar 3 memperlihatkan proses penulisan data pada kedua server database pusat beserta cara penanggulangan jika ada server database pusat yang mengalami kegagalan atau mati.

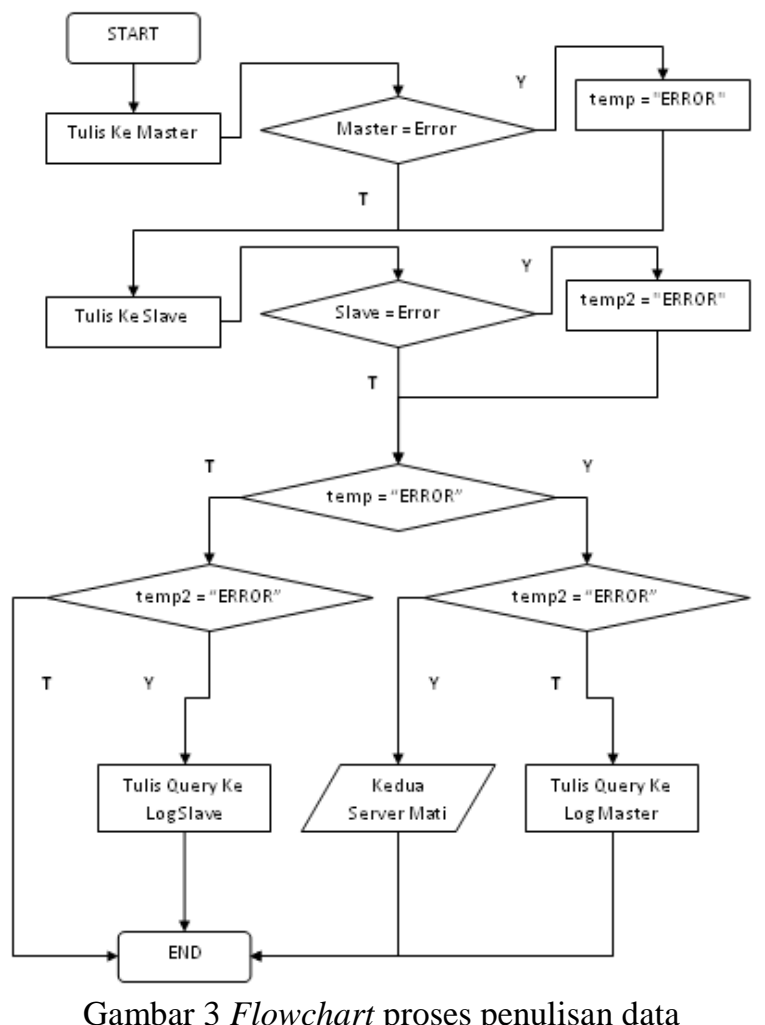

Proses tulis ke Master atau Slave terdiri dari proses insert, edit dan delete.

Pada Gambar 4 memperlihatkan proses pembacaan dari salah satu server database pusat yang masih hidup.

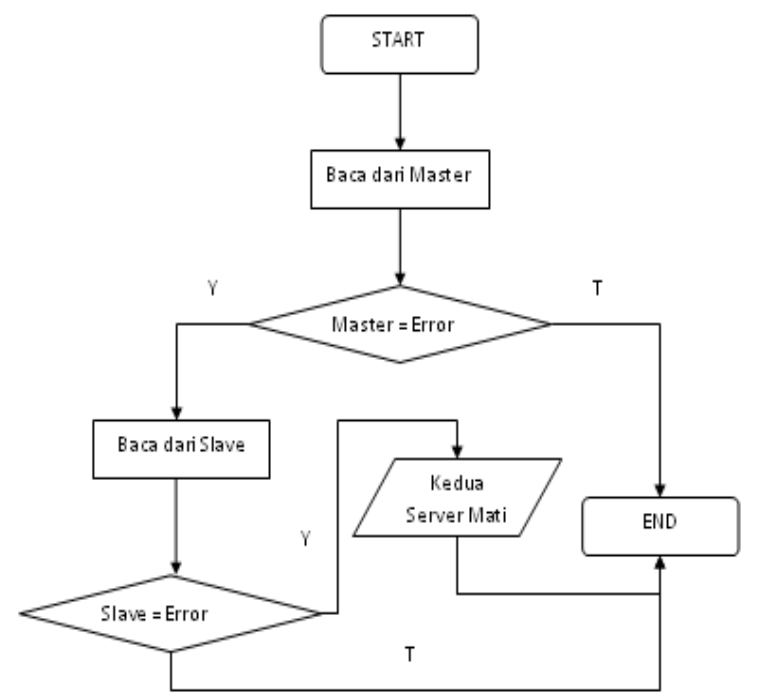

Gambar 4 Flowchart proses pembacaan data
Server database pusat yang mati tentunya mempunyai catatan query yang belum atau gagal dieksekusi di dalam database (log query). Dan sebelum server database pusat tersebut bisa kembali beroperasi haruslah dilakukan proses sinkronisasi terlebih dahulu. Untuk itu, semua query yang gagal dieksekusi sebelumnya haruslah bisa dieksekusi kembali. Query yang telah berhasil dieksekusi kembali bisa dihapus dari dalam database (log query). Gambar 5 memperlihatkan proses recovery data pada server database pusat.

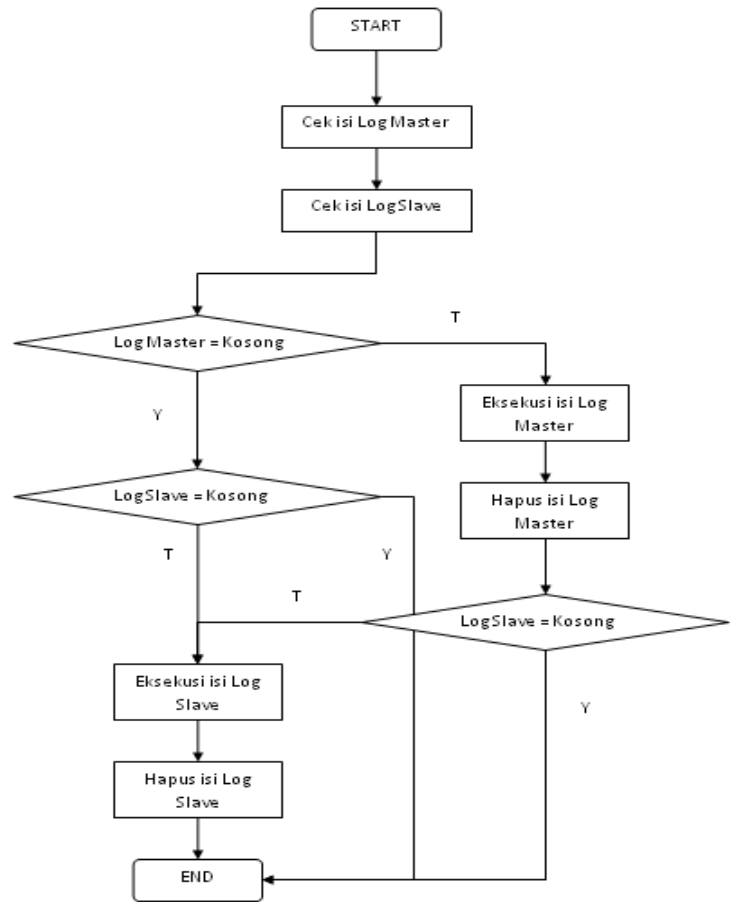

Gambar 5 Flowchart proses recovery data

\subsection{Implementasi Sistem}

Pada penelitian ini, pembuatan aplikasi Point Of Sale yang fault tolerant diimplementasikan dengan menggunakan bahasa pemrograman Visual Basic 6.0. Implementasi sistem ini sesuai dengan arsitektur yang telah dirancang sebelumnya. Dalam implementasi, sistem ini menggunakan peralatan sebagai berikut:

1. Perangkat keras

a. AMD Turion X2 Dual-Core Mobile RM$742,2 \mathrm{GHz}$

b. Hardisk $250 \mathrm{~GB}$

c. Memori RAM 4 GB - Dual Channel (128bit)

2. Perangkat lunak

a. Microsoft Windows XP

b. XAMPP for Windows 1.7.2 (MySQL 5.1.37) 
c. SQLyog Community Edition- MySQL GUI 8.12

d. MySQL Connector/ODBC 5.1

e. Microsoft Access 2003

f. Visual Basic 6.0

g. Oracle VirtualBox 3.2.6 r63112

Simulasi jaringan untuk sistem yang dibuat menggunakan bantuan software Virtual Machine yakni Virtual Box. Untuk client, coordinator, dan server database pusat menggunakan sistem operasi Windows XP. Server database pusat menggunakan software DBMS MySQL. Dan untuk database (log query) beserta database temporary pada client menggunakan software DBMS Microsoft Access 2003.

Sebelum bisa mengimplementasikan pembuatan aplikasi Point Of Sale yang fault tolerant, kita haruslah terlebih dahulu membangun arsitektur jaringan yang akan menunjang pengimplementasian aplikasi tersebut. Pada Gambar 6 akan memperlihatkan rancangan arsitektur jaringan yang digunakan dalam membangun sistem.

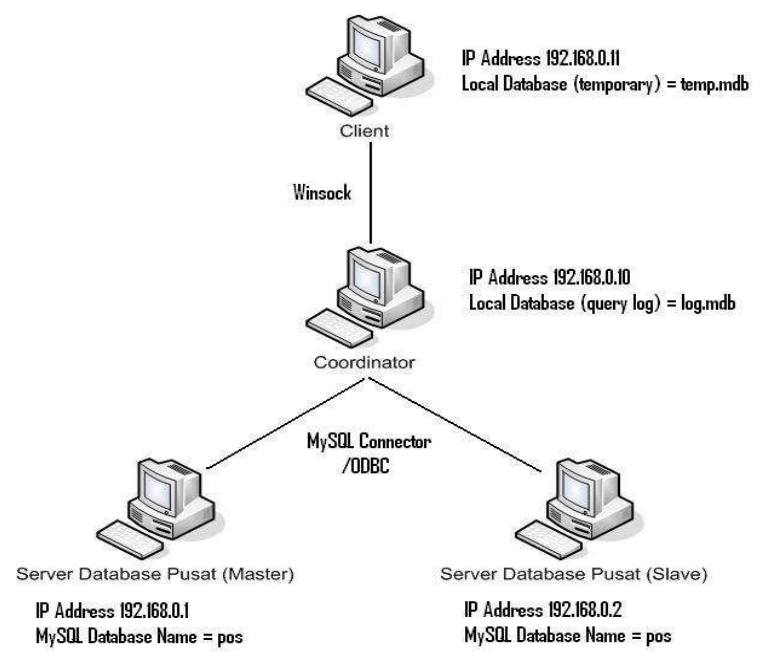

Gambar 6 Arsitektur jaringan sistem yang dibangun

Setelah memiliki jaringan yang bisa digunakan, barulah kita bisa segera mengimplementasikan pembuatan aplikasi yang kita inginkan. Agar penerapan arsitektur fault tolerant ini bisa berjalan dengan baik, maka availability dari coordinator haruslah bisa dijaga dengan baik.

Pengimplementasian dari aplikasi Point $O f$ Sale yang fault tolerant meliputi:

- Proses Pembacaan (Read One)

- Proses Penulisan (Write All)

- Proses Recovery

- Pada awal mulai dari coordinator

- Pada setiap selang waktu tertentu

\section{HASIL DAN PEMBAHASAN}

\subsection{Hasil Percobaan}

Sistem yang telah dirancang dan dibangun ini telah memperlihatkan kemampuannya dalam mengatasi kegagalan pengaksesan data pada salah satu server database pusat. Aplikasi Point Of Sale tersebut bisa tetap menjalankan tugasnya walaupun terdapat salah satu server database pusat yang mati. Dari percobaan yang dilakukan memperlihatkan sistem telah bisa menerapkan konsep pembacaan pada salah satu server database pusat dan penulisan terhadap semua server database pusat yang ada. Selain itu, sistem mempunyai kemampuan recovery untuk melakukan proses sinkronisasi data.

Percobaan yang dilakukan dengan mencoba melakukan pembacaan dan penulisan ketika server database pusat hidup keduanya, hanya server database pusat (master) yang hidup, hanya server database pusat (slave) yang hidup, ataupun keduanya mati.

\subsection{Pembahasan}

\subsubsection{Percobaan dengan master dan slave hidup}

Percobaan yang pertama dilakukan adalah dengan keadaan dimana kedua server database pusat hidup atau terkoneksi dengan baik. Dimana untuk operasi pembacaan, coordinator hanya akan melakukan pembacaan dari server database pusat (master). Dan untuk operasi penulisan akan dilakukan pada kedua server database pusat.

\subsubsection{Percobaan dengan master hidup dan slave mati}

Percobaan yang kedua dilakukan adalah dengan keadaan dimana server database pusat (master) hidup atau terkoneksi dengan baik, sedangkan server database pusat (slave) mati atau tidak terkoneksi. Dimana untuk operasi pembacaan, coordinator hanya akan melakukan pembacaan dari server database pusat (master). Dan untuk operasi penulisan akan hanya dilakukan pada server database pusat (master). Untuk keperluan proses recovery nantinya, operasi penulisan juga dilakukan terhadap tabel server 2 yang berada pada database (log query). Hal ini berguna untuk mencatat query penulisan yang gagal dieksekusi pada server database pusat (slave).

\subsubsection{Percobaan dengan master mati dan slave hidup}

Percobaan yang ketiga dilakukan adalah dengan keadaan dimana server database pusat (master) mati atau tidak terkoneksi, sedangkan 
server database pusat (slave) hidup atau terkoneksi dengan baik. Dimana untuk operasi pembacaan, coordinator hanya akan melakukan pembacaan dari server database pusat (slave). Dan untuk operasi penulisan akan hanya dilakukan pada server database pusat (slave). Untuk keperluan proses recovery nantinya, operasi penulisan juga dilakukan terhadap tabel serverl yang berada pada database (log query). Hal ini berguna untuk mencatat query penulisan yang gagal dieksekusi pada server database pusat (master).

\subsubsection{Percobaan dengan master dan slave mati}

Percobaan yang keempat dilakukan adalah dengan keadaan dimana kedua server database pusat (master dan slave) mati atau tidak terkoneksi. Pada keadaan seperti ini, coordinator akan berhenti melakukan tugasnya atau keluar. Hal ini dikarenakan untuk melakukan transaksi, aplikasi Point Of Sale perlu untuk melakukan pembacaan data barang seperti harga barang dari dalam server database pusat.

\section{KESIMPULAN}

Berdasarkan penelitian yang telah dilakukan, maka diambil beberapa kesimpulan sebagai berikut:

1. Penerapan arsitektur fault tolerant bisa dilakukan pada aplikasi Point Of Sale.

2. Arsitektur fault tolerant yang telah dibangun ini memiliki kemampuan dalam mengatasi permasalahan fail-silent fault pada salah satu server database pusat (master/slave).

3. Aplikasi Point Of Sale tetap bisa menjalankan proses transaksi walaupun terdapat salah satu server database pusat yang mati. Hal ini dikarenakan coordinator akan secara pintar memilih menggunakan server database pusat yang masih hidup.

4. Di bawah kendali dari coordinator, bila terdapat query penulisan yang gagal dieksekusi pada server database pusat (master atau slave), maka query tersebut akan dicatat pada database (log query) yang nantinya akan digunakan untuk proses recovery.

5. Proses recovery dilakukan pada 2 kondisi, yakni pada awal mulai dari coordinator atau pada setiap selang waktu tertentu.

\section{DAFTAR PUSTAKA}

[1] Budiyanto, A., 2005, Rancang Bangun Aplikasi Point Of Sale Berbasis Query Processing, Tesis, Magister Ilmu Komputer FMIPA UGM, Yogyakarta.

[2] Setyorini, T. A., 2010, Rancang Bangun Untuk Sistem Informasi Akademik yang Fault Tolerance, Tesis, Magister Ilmu Komputer FMIPA UGM, Yogyakarta.

[3] Ferdinando, H., 2004, Membangun Sistem Fault Tolerant Pada Fieldbus Untuk Aplikasi Sistem Terdistribusi, Seminar Nasional Ilmu Komputer dan Teknologi Informasi (SNIKTI), Bogor, 2-3 September 2004.

[4] Boon, Y. O., Huah, Y. C., dan Yu-N, C., 2010, Dynamic Service Placement and Redundancy: Concept and Research Direction, Proceedings of The Second International Conference on Distributed Framework \& Applications 2010, hlm. 47-52, Yogyakarta, 2-3 Agustus 2010.

[5] Vandiver, B., Balakrishnan, H., Liskov, B., dan Madden, S., 2006, Database Fault-Tolerance with Heterogeneous Replication,

http://publications.csail.mit.edu/abstracts/abstracts06/benmv/ benmv.html, diakses tanggal 18 Januari 2011.

[6] Coulouris, G., Dollimore, J., dan Kindberg, T., 2000, Distributed Systems Concepts and Design, $3^{\text {rd }}$ ed., Pearson Education Limited, China. 